\section{Gjensyn med klassiker om eksistensiell psykoterapi}

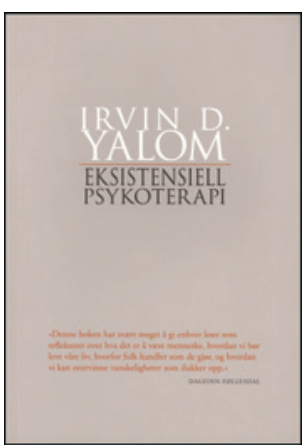

Irvin D. Yalom

Eksistensiell psykoterapi

618 s. Oslo: Arneberg forlag, 2011.

Pris NOK 399

ISBN 978-82-8220-015-8

Da den amerikanske psykiateren Irvin Yalom i 1980 utga sin store bok om eksistensiell psykoterapi, ga han et viktig supplement til den da rådende psykoanalytiske forståelse av det hjelpesøkende menneske. Yalom pekte på at Freuds psykodynamiske teori om at mennesket rommer motstridende krefter som kan resultere i psykopatologi, ikke dekker de eksistensielle dynamiske konfliktene som også kan utløse psykopatologi og uheldig mestring, dvs. hvert enkelt menneskes konfrontasjon med fire kjensgjerninger i tilværelsen: døden, frihet og ansvar for eget liv, isolasjonen («den djupa obotliga ensamheten») og meningsløsheten. Det er det filosofiske, empiriske og kliniske grunnlag for å la de eksistensielle utfordringene stå sentralt i dynamisk psykoterapi, som denne omfattende boka handler om.

Forfatteren spenner fra omtale av Heidegger og Sartre, til hans læremestere Rollo May, Victor Frankel og kollega Fritz Perls blant andre. Boka kan også leses som en slags faghistorie om det vell av psykoterapeutiske retninger som sprang ut i California på 1970-80 tallet, og som mange hevdet å være eksistensielle. Yalom diskuterer disse meget kritisk. Det samme gjør han med enkelte av Freuds postulater, noe som gir et interessant innblikk i den psykoanalytiske og eksistensielle diskursen på 1970 tallet.

Styrken i boka er utvilsomt forfatterens evne til å fortelle spennende, relevant og illustrerende kasuistikker hvor det å fokusere på eksistensielle spørsmål virker gunstig på pasienten. Mange eksempler er kreftpasienter og pasienter i ekteskapskrise. Dette er ikke noen «kokebok» i å drive eksistensiell terapi, men enhver terapeut, uansett skole, kan finne klinisk stoff til ettertanke. De eksistensielle spørsmål gjelder jo også hver og en av oss som er på terapeutsiden, og teksten stimulerer sannelig å reflektere over eget liv. Det kan gjøre det verdt å lese gjennom denne 618 siders murstein som ellers har litt «gammelmodig» faglig preg (1960-80 tallet) og er litt for ordrik og litt for omstendelig når det gjelder å referere en heller tynn forskningslitteratur. For kolleger som praktiserer eller utdanner seg til psykoterapeuter, er vel dette en av de bøker som man før eller siden bør ha lest. Da vil du også én gang til måtte prøve å svare på: Hvor er jeg, hvor skal jeg, hva gjør jeg ut av livet mitt?

\section{Per Vaglum}

Avdeling for medisinsk atferdsforskning

Institutt for medisinske basalfag

Universitetet i Oslo

\section{Hvem stirrer fra veggen?}

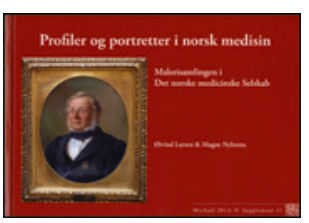

Øivind Larsen, Magne Nylenna Profiler og portretter i norsk medisin Malerisamlingen i Det norske medicinske Selskab. 142 s, ill. Oslo: Det norske medicinske Selskab, 2012. Pris NOK 250 ISBN 978-82-92871-94-2

Alvorlige eldre leger stirrer på oss. Noen er i sin beste stas med diplomatfrakk og høy snipp, og mange av dem er prydet med ordener i gull og emalje. Andre er i gallauniform fra Forsvaret med forgylte epåletter. Mange har skjegg, andre har knebelsbart, mens noen er glattraket. Ikke et smil er å se, men på noen av bildene aner jeg et muntert glimt i øyet. For så alvorlige var de ikke når det kom til stykket. Mange kjente navn fra norsk medisin passerer forbi, og om flere av dem verserer det fortsatt morsomme anekdoter. Blant dem er Søren Bloch Laache, Kristian Brandt og Fredrik Georg Gade. Noen av personene gikk bare under oppnavn, og det fornemste av dem var «Keiseren». Intet mindre.

Øivind Larsen og Magne Nylenna, begge nestorer i norsk medisin, har gjort oss den tjenesten å skape liv i den store portrettsamlingen til Det norske medicinske Selskab i Oslo. Etter årelangt arbeid presenterer de en liten, men samtidig innholdsrik bok der de forteller om personene bak portrettene, litt om deres samtid og hva de utrettet. De forteller også om miljøet rundt dem, litt om ulike institusjoner der de arbeidet, og om hvordan de var knyttet til Selskabet på forskjellige måter. Resultatet er blitt en særdeles interessant og lettlest bok om sentrale personer i norsk medisinsk historie. Flere av de portretterte personene har internasjonal berømmelse.

Boken er kronologisk oppbygd med korte, biografiske skildringer av personene. Illustrasjoner og formgiving er førsteklasses, og gjennom faktabokser får vi vite mye om både sentrale emner i medisinens utvikling og om institusjonshistorie. Som forventet er det få kvinner blant portrettene, men det vil forandre seg raskt i neste generasjon av fremtidige portretter - nå som nærmere tre firedeler av medisinstudentene er kvinner. Dessuten tipper jeg at blant portretterte sykepleiere som har gjort en pionerinnsats $i$ arbeidet, er det ingen menn i det hele tatt.

Boken vil ha stor interesse for alle som er engasjert i norsk helsehistorie og ønsker å vite mer om pionerene i medisinen. Ikke minst er den kort og lettlest og et funn for talere, men de mest frodige anekdotene må man lete etter andre steder.

Både forfatterne og tidsskriftet Michael, som står som utgiver, gratuleres med et kjærkomment tilskudd til medisinens personalhistorie.

\section{Ole Didrik Lærum}

Voss 